\title{
Movements of Islamic Stock Indices in Selected OIC Countries
}

\author{
Rininta Nurrachmi \\ Department of Economic \\ Kulliyah of Economics and Management Science \\ International Islamic University Malaysia, Jalan Gombak Kuala Lumpur, Malaysia, \\ email: rini.martam@gmail.com
}

\begin{abstract}
This study reviews the movement of Islamic stock indices in selected countries in the Organization of Islamic Cooperation (OIC) with high number of muslim population namely Indonesia, Malaysia, Turkey, Qatar, Bahrain, and Oman. The objectives are to examine the changes in cross market linkage among six selected OIC countries during crisis and after 2007 crisis and to analyze whether the international investor can gain benefit when allocating their funds across these markets. The set of relationship for each pair of Islamic stock index is analyzed using Engel-Granger (1987) and Autoregressive Distribution Lagged (ARDL) bound testing approach. The analysis is made for the sub period during crisis is 3 September 2007 - 11 January 2010 and post crisis is 18 January 2010 - 30 April 2013. The result depicts that there are evidences of cointegration among the Islamic stock markets after crisis but not during crisis. The long-run relationship indicates that investors can gain portfolio diversification benefit across these six countries.
\end{abstract}

Keywords: Financial crisis, Islamic finance, Islamic stock index, market integration, OIC countries

\begin{abstract}
Abstrak Penelitian ini meninjau negara-negara terkemuka dengan jumlah penduduk muslim yang tinggi di OKI (Organisasi Kerjasama Islam), yaitu Indonesia, Malaysia, Turki, Qatar, Bahrain, dan Oman untuk mengamati pergerakan indeks syariah. Perumusan masalah yang ingin dicapai adalah untuk menguji keberadaan integrasi pasar indeks saham syariah pada saat terjadinya krisis dan setelah krisis di tahun 2007 dan untuk menganalisis apakah investor internasional dapat memperoleh manfaat ketika mengalokasikan dana mereka di pasar-pasar saham ini. Pengujian hubungan antara indeks saham syariah menggunakan Engel- Granger (1987) dan Autoregressive Distribution Lagged (ARDL). Analisis dilakukan dengan sub periode saat terjadi krisis, yaitu mulai 3 September 2007 sampai 11 Januari 2010 dan setelah krisis tahun 2007 mulai 18 Januari 2010 sampai 30 April 2013. Hasilnya menggambarkan bahwa kointegrasi hadir di pasar saham syariah setelah krisis tetapi tidak pada saat terjadinya krisis. Hubungan jangka panjang menunjukkan bahwa investor dapat memperoleh keuntungan portofolio di enam negara ini.
\end{abstract}

Kata kunci: Indeks saham syariah, integrasi pasar, krisis keuangan, negara-negara OKI

\section{INTRODUCTION}

The study by Majid and Kassim (2007) argue that stock market integration provides important information on the prospective international diversification opportunities for investors. Stock markets which are highly cointegrated suggests the non-existence of diversification benefits since the performance and returns in these markets are highly correlated with each other. With the increasing contribution of Islamic finance in the global market, the increased number of Muslim population in the world, sharia compliance product has the potential avenue for portfolio diversification. However, the existence of integration in Islamic stock market for Muslim countries indicates that diversification benefit is not yet explored in the previous studies.

Most of the countries in OIC (Organization of Islamic Cooperation) rely on the revenue from the export of natural resources, such as oil and gas, and agricultural products. In term of investment, developed countries remain the top rank in terms of market capitalization namely the United State with USD 18,668 billion, China with USD 3,697 billion, and Japan with USD 3,680 billion (World Bank, 2013). With the rapid growth of Islamic capital market at the global level, the OIC countries should expedite 
on the efforts to expand their capital market and gradually diversify their sources of revenues rather relying on its export of natural resources.

Several advantages can be obtained from stock market integration in the OIC members. Besides making the market more efficient and competitive through investors' diversification, the OIC member can get access to broader range of shares such as stock with low and high prices, price stock that spread for a defined period of day, month or year and stock price volatility. There are empirical studies elaborate the existence of stock market integration in OIC countries (Marashdeh, 2005; Ergun \& Hassan, 2007; Majid et al., 2007; Nor, 2012; Paskelian et al., 2013). These studies mentioned that stock market integration present in the OIC members. These works are conducted for conventional stock market in OIC countries. There are few studies done on Islamic stock market but not specified to examine the present of cointegration of Islamic stock market in OIC countries. It will be interesting to know whether long-run relation in Islamic stock markets exist within OIC countries where Islam is the main religion. Looking through empirical investigation on selected Islamic stock markets linkages from different region in the period during and post crisis, this paper intends to achieve the following objectives:

1 To examine the changes in the cross market linkage among six selected OIC countries during crisis and post 2007 crisis.

2 To analyze whether the OIC Islamic stock markets are segmented or the international investors can get the benefits when allocating their funds across these markets.

\section{LITERATURE REVIEW}

\section{The Performance of Islamic Stock Market in OIC}

The purpose of Islamic stock market is to facilitate the flow of funds from surplus unit to deficit units but does not allowed riba, injustice, cheating and, lying transaction involved in it. The deficit units refer to business enterprises who want to issue equity capital in order to raise new funds. The activities carried out by Islamic equity market are guided by the Islamic law or sharia which derived from the main sources of Islam namely the holy Quran and Sunnah (traditions of Prophet Muhammad). In Islamic stock market, before the company is listed in the sharia index, it has to pass the screening criteria which is deemed as haram (sinful) according to sharia, namely riba, gharar (uncertainty), maysir (gambling), producing pork, liquor, tobacco, weapon, and activities that are considered immoral which include unIslamic entertainment, casino, pornography, and prostitution.

Since The Dow Jones \& Company launched the Dow Jones Islamic Market World (DJIM) index series in 1999 this industry is growing well within OIC countries. It expanded for 69 country level of DJIM. The index was first launched in Bahrain and it was the first index created for investors seeking investments in compliance with Muslim sharia law.

A few years later there are two Islamic indices series launched in 2007, they are the FTSE Sharia Global Equity Index Series and the MSCI (Morgan Stanley Capital International) Global Islamic Indices. FTSE Sharia Global Equity Index Series covers all regions across both developed and emerging markets to create a comprehensive sharia indexing solution. The FTSE Sharia Global Equity Index Series is based on the large and mid-cap stocks in the FTSE Global Equity Index Series universe. The sharia screening process is undertaken by sharia consultants, Yasaar Limited against a set of guiding principles. Bursa Malaysia joint FTSE group in 2007 for index measurement for its sharia compliant securities. Prior working with FTSE group, Kuala Lumpur Stock Exchange (KLSE) Sharia Index introduced in 1997. There are three Islamic index launched by Bursa Malaysia and FTSE Group, namely FTSE Bursa Malaysia Hijrah Sharia Index, FTSE Bursa Malaysia Emas Sharia Index, and FTSE Bursa Malaysia Small Cap Sharia Index.

There was another Global Islamic stock indices launched in March 2007, MSCI (Morgan Stanley Capital International) Global Islamic Indices which were constructed from conventional MSCI country indices. The MSCI Global Islamic Indices cover over 50 developed and emerging countries and over 
50 regions such as the Gulf Cooperation Council (GCC) countries and Arabian markets. Turkey, Oman and Qatar apply MSCI Global Islamic Indices for their stock index measurement. Besides applying Global Islamic indices in their index measurement, Indonesia has developed its own Islamic index, Jakarta Islamic Index (JII). The index was established in 3 July 2000 and JII consists of the 30 most liquid Islamic shares that listed in Indonesia Stock Exchange (IDX).

The following table is market capitalization for selected OIC countries. Malaysia has the highest number compare to other countries during 2007 to 2012, followed by Indonesia as the second rank but apparently countries in the Middle East are placed at the bottom three after Turkey. Most countries in the Middle East depends their income from export of natural gas and oil, thus revenue from stock market is not significant. Global crisis had caused a plunged in market capitalization in the year 2008 and 2009 for all members with around 40 to 70 percent.

Table 1 Stock market capitalization for selected OIC countries (in million US Dollar)

\begin{tabular}{clcccccc}
\hline \multirow{2}{*}{ No } & $\begin{array}{c}\text { Country } \\
\text { Name }\end{array}$ & 2007 & 2008 & 2009 & 2010 & 2011 & 2012 \\
\hline 1 & Malaysia & 325,663 & 187,066 & 255,952 & 410,534 & 395,083 & 476,340 \\
2 & Indonesia & 211,693 & 98,761 & 178,191 & 360,389 & 390,107 & 396,772 \\
3 & Turkey & 286,572 & 117,930 & 225,735 & 306,662 & 201,817 & 308,775 \\
4 & Qatar & 95,488 & 76,307 & 87,856 & 123,592 & 125,413 & 126,371 \\
5 & Oman & 23,060 & 14,914 & 17,302 & 20,267 & 19,719 & 20,107 \\
6 & Bahrain & 28,134 & 21,177 & 16,933 & 20,429 & 17,152 & 16,065 \\
\hline
\end{tabular}

Source: World Bank (2013)

\section{Stock Market Integration in OIC Countries}

Numerous studies analyzed the interrelation between stock exchanges in the Muslim countries. The earlier studies by Darrat et al. (2000), Neaime (2005), and Marashdeh (2005) investigate MENA (Middle East and North Africa) region and discover that long-run relationship existed among these regions. Neaime (2005) divides eight MENA countries namely Egypt, Morocco, Turkey, and Jordan to has the most open and financially integrated. While the least regulated markets in MENA and considered to be less financially integrated and highly regulated financial markets are Saudi Arabia, Kuwait, Bahrain, and the UAE. Study by Nor (2012) indicates that financial market integration present in MENA region (Saudi Arabia, Tunisia, Egypt, and Oman) and claim that the stock market was not efficient because the predictability of these markets. The work applies VECM to analyze daily stock indices from the market indices of these four emerging economies from April 1999 until December 2008.

In the scope of OIC countries, studies on conventional stock market integration showed different result. Ceylan and Dogan (2004) point out there was stock market integration among eight OIC countries (Egypt, Jordan, Kuwait, Lebanon, Morocco, Oman, Pakistan, and Turkey) following 11 September 2001 incident. They assign Dynamic OLS (Ordinary Least Square) and Engle-Granger for analysis and divide the sample size into two periods, pre 9/11 and post 9/11. Majid et al. (2007) include Asian region (Malaysia, Indonesia, Bangladesh, and Pakistan) and MENA region (Turkey, Egypt, Oman, and Kuwait) in the research. They report that stock market integration was only existed in Asian region of OIC countries. Ergun and Hassan (2009) examine four OIC countries (Turkey, Malaysia, Indonesia and Pakistan) and found that there was a long-run relationship. Both studies relied their estimation on VECM (Vector Error Correction Model).

Although literatures on Islamic stock market integration are not as vast as conventional stock market, there have been few studies explored the issue in this Islamic finance industry. Prior sub-prime crisis Majid and Kassim (2010) reviewed that Islamic stock market in Malaysia and Indonesia closely integrated with each other in the year 1999 to 2006. The study argued that the reason for stock market to be cointegrated due to the level of economic development of the country where both countries are 
emerging market. To achieve the objective, they applied two steps estimation, Auto Regressive Distributed Lag (ARDL) and the Vector Error Correction Model (VECM) based on the Generalized Method of Moments (GMM).

Beik and Wardhana (2011) also observe Indonesia's Islamic stock market. They employed VAR (Vector Autoregression) to examine the relationship between Jakarta Islamic Index (JII) with other Islamic as well as conventional stock markets in Malaysia and the United States during the subprime crisis. Non-existence of cointegration come out in their study and for investor the result will give them choices for their investment portfolio. While for Indonesia's stock market, this condition was an opportunity to promote its capital market as potential destination for profitable investment. Latest study by Hussin et al. (2013) show that equilibrium relationship does not exist among FTSE Bursa Malaysia Emas Sharia (FBMES), Jakarta Islamic Index (JAKISL), and Dow Jones Islamic Market index (DJIM). The non-integrated Islamic stock market will provide rooms for local and international investors to diversify their investment portfolios. They used VAR (Vector Autoregression) to observe the Islamic stock market in Indonesia, Malaysia, and the world.

To analyze the changes of interrelation among stock markets linkage, Karim et al. (2010), Karim and Karim (2012), Kassim (2013), and Kenani et al. (2013) divide the sample size into sub-sample. For conventional stock market, Karim and Karim (2012) investigate five countries of ASEAN in emerging stock market during pre, post 1997 and post US sub-prime mortgage. The result reveal that ASEAN stock markets were integrated during pre, post-1997 and post subprime financial crisis. During postsubprime crisis the degrees of short and long-run integration have significantly increased. The finding indicated that investors who diversified their investment across the ASEAN markets could only gain limited benefits during the period of subprime crisis. Kenani et al. (2013) divide the sample into before and after 2008 Global Financial Crisis (GFC) to analyze the integration between Chinese stock market with Indonesian stock market. The study also included the volatility spillovers effects of Japan and the US on Indonesian and Chinese stock market by employing Exponential GARCH (EGARCH) model for analysis. The result mentioned that there was an increase in market linkage between Chinese stock market with Indonesian stock market after GFC and the role of GFC has played its important role in integrating two economies. It implies that investors have limited gains from portfolio diversification from these markets.

For Islamic stock market, Karim et al. (2010) report no evidence of cointegration among countries such as Malaysia, Indonesia, the United Kingdom, the United State and Japan before crisis and during the crisis of sub-prime mortgage. However other study by Kassim (2013) claims that global financial crisis has caused changes in Islamic stock market integration level during the crisis and non-crisis period. The analysis was conducted for developed (the United States, the United Kingdom, and Japan) and developing (Indonesia, Malaysia, Kuwait, and Turkey) countries.

Numerous studies (Darrat et al., 2000; Ceylan \& Dogan, 2004; Marashdeh, 2005; Majid \& Kassim, 2010; Karim \& Karim, 2012; and Kenani et al., 2013) illustrate that if there is stock market linkage within countries, investors can only gain limited benefit from portfolio diversification because the performance and returns of the market are correlated with each other. When the stock market is integrated the market becomes inefficient because it is predictable. During OIC Stock Exhange Forum in 2010, there were many benefits can be access for OIC countries from stock market integration such as follow:

1 The market becomes more efficient and competitive;

2 Because efficient and competitiveness in the market, the cost of transaction will be lower and the return for the stock will be higher;

3 Investors could gain access to a broader range of shares;

4 Issuers could gain access to a larger number of investors;

5 Increased cross-border capital flows;

6 Risk could be diversified in a wider market, and

7 Reduction of market risk volatility due to increase in the market size. 
With different condition of stock market in terms of legal jurisdiction, income level and the maturity of stock market development, Hassan and Yu (2007) recommend that there should be a set of internationally and implementation in order that the policy maker can form the basic development of sound stock exchange in OIC countries. Moreover, countries in OIC should establish stock market linkages with other exchanges because the different condition of stock exchange and the difficulties to generate foreign trading volume due to small and illiquid stock market. This form of cross-border linkages will achieve cost savings from many different sources namely economy of scale, sharing system for equity trading and harmonizing rules and requirements between stock exchanges with respect to trading and membership (Claessens et al., 2003)1.

\section{METHOD}

\section{Data}

There are 57 members of OIC but the study focuses on six representatives OIC Islamic stock market because of data availability and the existence of their Islamic stock markets. The time series data sets consist of two countries in South East Asia region (Indonesia and Malaysia), one country in Europe and Central Asia (Turkey) and three countries in the Middle East and North Africa (Qatar, Oman, and Bahrain).

Daily closing stock indices collected from Bloomberg Database covering the period of six years from 3 September 2007 to 30 April 2013. The beginning of sample period based on the data availability for all stock index while for the ending period is the latest data at the time of data collection. The purpose of this study is to analyze the impact of GFC (Global Financial Crisis) on the integration of Islamic stock market during and post crisis. To examine the changes in the cross market linkage among six selected OIC countries, the study divides the sample period for analysis into two, during crisis (from 3 September 2007 to 11 January 2010) and post crisis (from 18 January 2010 to 30 April 2013).

\section{ARDL Bound Testing Approach}

The study applies autoregressive distributed lag approach to cointegration (ARDL) developed by Pesaran and Shin (1995). The benefit of this method is that it can be employed regardless the stationary properties of the variables in the sample and allows for inferences on long-run estimates, which is impossible under alternative cointegration procedures. We can say that this tool may be applied irrespective of whether the condition of the series are I(0) or I(1). To achieve our objective the following model is used in the study:

Indonesia (1)

$\operatorname{LnINDO}_{t}=\beta_{0}+\beta_{1} \operatorname{LnMY}_{t}+\beta_{2} \operatorname{LnTURK}_{t}+\beta_{3} \operatorname{LnQATR}_{t}+\beta_{4} \operatorname{LnBAHRN}_{t}+\beta_{5} \operatorname{LnOMAN}_{t}+\varepsilon_{t}$

Malaysia (2)

$\operatorname{LnMY}_{t}=\beta_{0}+\beta_{1} \operatorname{LnINDO}_{t}+\beta_{2} \operatorname{LnTURK}_{t}+\beta_{3} \operatorname{LnQATR}_{t}+\beta_{4} \operatorname{LnBAHRN}_{t}+\beta_{5} \operatorname{LnOMAN}_{t}+\varepsilon_{t}$

Turkey (3)

$\operatorname{LnTURK}_{t}=\beta_{0}+\beta_{1} \operatorname{LnINDO}_{t}+\beta_{2} \operatorname{LnMY}_{t}+\beta_{3} \operatorname{LnQATR}_{t}+\beta_{4} \operatorname{LnBAHRN}_{t}+\beta_{5} \operatorname{LnOMAN}_{t}+\varepsilon_{t}$

Qatar (4)

$\operatorname{LnQATR}_{t}=\beta_{0}+\beta_{1} \operatorname{LnINDO}_{t}+\beta_{2} \operatorname{LnTURK}_{t}+\beta_{3} \operatorname{LnMY}_{t}+\beta_{4} \operatorname{LnBAHRN}_{t}+\beta_{5} \operatorname{LnOMAN}_{t}+\varepsilon_{t}$

Bahrain (5)

$\operatorname{LnBAHRN}_{t}=\beta_{0}+\beta_{1} \operatorname{LnINDO}_{t}+\beta_{2} \operatorname{LnTURK}_{t}+\beta_{3} \operatorname{LnQATR}_{t}+\beta_{4} \operatorname{LnMY}_{t}+\beta_{5} \operatorname{LnOMAN}_{t}+\varepsilon_{t}$

\footnotetext{
${ }^{1}$ Retrieved from Hasan and Yu (2007)
} 
Oman (6)

$\operatorname{LnOMAN}_{t}=\beta_{0}+\beta_{1} \operatorname{LnINDO}_{t}+\beta_{2} \operatorname{LnTURK}_{t}+\beta_{3} \operatorname{LnQATR}_{t}+\beta_{4} \operatorname{LnBAHRN}_{t}+\beta_{5} \operatorname{LnMY}_{t}+\varepsilon_{t}$

Where LnINDO, LnMY, LnTURK, LnQATR, LnBAHRN, LnOMAN refers to the natural $\log$ of Islamic stock market of Indonesia, Malaysia, Turkey, Qatar, Bahrain, and Oman respectively and $\varepsilon_{t}$ is the error term for the model.

The application of bound test is consider as a vector of variables : $A_{t}$ where $A_{t}=\left(y_{t} x_{t}\right)$, the dependent variables is $y_{t}$ and the vector of regressors is $x_{t}$. The data generating process of $A_{t}$ is p-order vector autoregression. To analyze the integration, $\Delta y_{t}$ is modeled as a conditional Error-Correction Model as follows:

$$
\Delta y_{t}=\alpha_{0}+\pi_{y y} y_{t-1}+\pi_{y x, x} x_{t-1}+\sum_{i=1}^{p} \partial_{i} \Delta y_{t-i}+\sum_{i=0}^{p} \propto_{i} \Delta y_{t-i}+\mu_{t}
$$

The symbol for $\pi_{y y}$ and $\pi_{y x, x}$ are long-run multipliers, is the drift. Lagged values of $\Delta y_{t}$ and current and lagged values of $\Delta x_{t}$ are used to model the short-run dynamic structure. The existence of integration is traced by restricting all estimated coefficient of lagged level variables equal to zero, that is the null.

Here, $\pi y y$ and $\pi y x . x$ are long-run multipliers, is the drift. Lagged values of $\Delta y t$ and current and lagged values of $\Delta x t$ are used to model the short-run dynamic structure. The existence of cointegration is traced by restricting all estimating coefficient of lagged level variables equal to zero. Whereas, the null hypothesis $H_{0}: \pi_{y y}=\pi_{y x, x}=0$ against the alternative, hypothesis $H_{1}: \pi_{y y} \neq \pi_{y x, x} \neq 0$. These hypotheses can be checked using the critical values bounds as tabulated in Pesaran et al. (2001). The relevant critical values bounds are based on case III in Pesaran et al. (2001) study with unrestricted intercept and no trend and number of regressors (k). There are two sets of critical values for F-test in which upper and lower bounds are provided for I (0), I (1) or mutually cointegrated regressors. If the calculated F-statistics exceeds upper bound, then the variables are cointegrated and null hypothesis of no cointegration amidst the variables are rejected while the variables fall below the lower bound then null hypothesis of no cointegration is accepted. However, if the variables fall between upper and lower bounds then the result is inconclusive whether variables are cointegrated or not. Based on study by Narayan (2004), the benefit of ARDL approach is we can estimate which series is the dependent variable from F-test when there is a cointegration.

The above mention model is based on the assumption that the error term is serially uncorrelated. Hence, it is important that the lag order $\mathrm{p}$ of the underlying model is appropriately chosen (Pesaran et al., 2001). The order of the distributed lag on the dependent variable and the regressors is choose by using either Akaike Information Criterion (AIC) or the Schwartz Bayenisian Criterion (SBC).

\section{RESULTS AND DISCUSSIONS}

\section{Descriptive Analysis}

The purpose of descriptive analysis is to provide the nature and the volatility performance as a preliminary test prior conducting the main test, which is ARDL. It also used as a tool to compare the basic performance indicators of the stock indices to ease the analysis in how the stock indices fare against each other. Table 2 depicts summary statistics on the stock returns (i.e. stock prices in first difference) for the selected Islamic stock markets.

Islamic stock market in Bahrain was the most active and profitable during crisis period, which shown with the highest average daily returns of $0.2 \%$. The following percentages held by Turkey at $0.06 \%$, Qatar at $0.01 \%$, Malaysia at $-0.01 \%$, Oman at $-0.03 \%$, and Indonesia at $-0.04 \%$. As we can see, the most profitable Islamic stock markets are countries where the government supports the development of Islamic finance and the center for Islamic finance. In terms of volatility returns (as illustrated by the 82 
standard deviation), Qatar documented the highest volatility with $3.67 \%$ followed by Turkey with $3.63 \%$, Indonesia with $3.47 \%$, Bahrain with $2.65 \%$, Oman with $2.57 \%$, and Malaysia with $1.53 \%$.

While the statistic for post crisis, Bahrain still maintain its position as the most active and profitable for Islamic stock market, followed by Oman at $0.03 \%$, Qatar at $-0.046 \%$, Malaysia at $-0.049 \%$, Turkey at $-0.05 \%$, and Indonesia $-0.065 \%$. For the volatility returns the top three held by Turkey at $2.3 \%$, Indonesia $1.7 \%$, and Bahrain $-1.25 \%$. The latter positions hold by Qatar at $1.05 \%$, Oman at $0.9 \%$, and Malaysia $0.72 \%$.

In general, the Islamic stock market during crisis period was more volatile than after the crisis. With unique character in sharia compliant securities apparently have attracted investors to invest in Islamic stock market. The Sharia compliant product avoid to include riba, injustice, and lying transaction in it. Hence the investors see the product to be more profitable and gain more return during the crisis whereas most of conventional products gain loss.

Table 2 Descriptive statistics of Islamic stock market returns

\begin{tabular}{lcccccc}
\hline & $\begin{array}{c}\text { Jakarta } \\
\text { Islamic } \\
\text { index }\end{array}$ & $\begin{array}{c}\text { FBM Hijrah } \\
\text { Sharia } \\
\text { Index }\end{array}$ & $\begin{array}{c}\text { MSCI } \\
\text { Islamic } \\
\text { Index }\end{array}$ & $\begin{array}{c}\text { MSCI Qatar } \\
\text { Islamic } \\
\text { Index }\end{array}$ & $\begin{array}{c}\text { Bahrain } \\
\text { Islamic } \\
\text { Index }\end{array}$ & $\begin{array}{c}\text { MSCI } \\
\text { Oman } \\
\text { Islamic } \\
\text { Index }\end{array}$ \\
\hline Mean & -0.000438 & -0.000116 & 0.000619 & 0.00012 & 0.002726 & -0.000271 \\
Median & -0.001631 & -0.000254 & 0.000917 & 0 & 0.000305 & -0.000837 \\
Maximum & 0.303865 & 0.118934 & 0.256839 & 0.22773 & 0.160001 & 0.168944 \\
Minimum & -0.225167 & -0.064653 & -0.223328 & -0.227095 & -0.099391 & -0.177167 \\
Std. Dev. & 0.034731 & 0.015325 & 0.03633 & 0.036768 & 0.026539 & 0.025697 \\
\hline & & \multicolumn{7}{c}{ Post Crisis Period } & & \\
\hline Mean & -0.000655 & -0.000497 & -0.000504 & -0.000461 & 0.001275 & 0.000348 \\
Median & -0.001582 & -0.000942 & -0.001457 & -0.000553 & 0 & 0.000132 \\
Maximum & 0.102139 & 0.040737 & 0.087237 & 0.042884 & 0.068284 & 0.074899 \\
Minimum & -0.067345 & -0.023663 & -0.098903 & -0.06483 & -0.070868 & -0.055501 \\
Std. Dev. & 0.017611 & 0.007178 & 0.02333 & 0.010511 & 0.012523 & 0.009052 \\
\hline
\end{tabular}

\section{ARDL Analysis}

To indicate which stock market give influence to other stock market, Granger causality test assist us to determine the direction of causation. In Table 3 and Table 4 are the regression of Granger Causality Direction ( $\mathrm{Lag}=2)$ at $10 \%, 5 \%$, and 1\% significance level during and after 2007 crisis. Overall values illustrated significance level at $1 \%$ among six OIC members during and post crisis.

In Table 5, the summary of granger causality was measured at $1 \%$ significance level. During the crisis there was bi-directional causality between market in Qatar with market in South East Asian countries such as Indonesia and Malaysia. These significant causalities recommend that the stock markets were correlated within Qatar, Malaysia, and Indonesia, and in such a way that any changes in particular stock market provide a similar impact on the other stock markets, hence the benefits from market diversification of these countries lessen. While the remaining countries such as Turkey and Bahrain seem to have only one direction with Malaysia and Indonesia. This condition might indicate that there is market diversification between Malaysia and Indonesia with Turkey and Bahrain, moreover the opportunity for portfolio diversification among these countries can be enhanced. 
The result after the crisis, Malaysia and Indonesia are the only country with significance bi-directional causality. The correlation between these two markets happened due to level of economic development of country where both countries are emerging market, similar with study conducted by Majid and Kassim (2010). Although the platform of legal aspect in Islamic stock market for Malaysia and Indonesia is different, both countries has collaborated in human resource development such as student exchange, training, conference, and workshop.

Table 3 Granger Causality Direction (lag $=2$ ) during crisis

\begin{tabular}{|c|c|c|c|c|}
\hline Countries & Sample Size & F-Statistic & P-Value & Result \\
\hline Malaysia - Indonesia & 423 & 5.90377 & $0.003 *$ & Significant at $1 \%$ \\
\hline Indonesia - Malaysia & & 0.98997 & 0.3725 & Not Significant \\
\hline Turkey - Indonesia & 423 & 4.43968 & $0.0124 * *$ & Significant at 5\% \\
\hline Indonesia - Turkey & & 5.10093 & $0.0065^{*}$ & Significant at $1 \%$ \\
\hline Qatar-Indonesia & 423 & 6.09067 & $0.0025^{*}$ & Significant at $1 \%$ \\
\hline Indonesia - Qatar & & 5.87723 & $0.003^{*}$ & Significant at $1 \%$ \\
\hline Bahrain - Indonesia & 423 & 3.93485 & $0.0203 * *$ & Significant at $1 \%$ \\
\hline Indonesia - Bahrain & & 3.78855 & $0.0234 * *$ & Significant at $1 \%$ \\
\hline Oman - Indonesia & 423 & 8.91992 & $0.0002 *$ & Significant at $1 \%$ \\
\hline Indonesia - Oman & & 2.16431 & 0.1161 & Not Significant \\
\hline Turkey - Malaysia & 423 & 3.75209 & $0.0243 * *$ & Significant at $5 \%$ \\
\hline Malaysia - Turkey & & 7.82862 & $0.0005^{*}$ & Significant at $1 \%$ \\
\hline Qatar-Malaysia & 423 & 5.98519 & $0.0027^{*}$ & Significant at $1 \%$ \\
\hline Malaysia - Qatar & & 6.12299 & $0.0024 *$ & Significant at $1 \%$ \\
\hline Countries & Sample Size & F-Statistic & P-Value & Result \\
\hline Bahrain - Malaysia & 423 & 4.25749 & $0.0148 * *$ & Not Significant \\
\hline Malaysia - Bahrain & & 2.72161 & $0.0669 * * *$ & Not Significant \\
\hline Oman - Malaysia & 423 & 9.31907 & $0.0001 *$ & Significant at $1 \%$ \\
\hline Malaysia-Oman & & 2.75636 & $0.0647 * * *$ & Not Significant \\
\hline Qatar-Turkey & 423 & 4.16341 & $0.0162 * *$ & Not Significant \\
\hline Turkey - Qatar & & 2.38266 & $0.0936 * * *$ & Not Significant \\
\hline Bahrain - Turkey & 423 & 5.22188 & $0.0058^{*}$ & Significant at $1 \%$ \\
\hline Turkey - Bahrain & & 1.1398 & 0.3209 & Not Significant \\
\hline Oman - Turkey & 423 & 8.39763 & $0.0003^{*}$ & Significant at $1 \%$ \\
\hline Turkey - Oman & & 0.94976 & 0.3877 & Not Significant \\
\hline Bahrain - Qatar & 423 & 1.68666 & 0.1864 & Not Significant \\
\hline Qatar-Bahrain & & 3.60228 & $0.0281 * *$ & Not Significant \\
\hline
\end{tabular}




\begin{tabular}{lcccc} 
Oman - Qatar & 423 & 18.3702 & $0.00000002 *$ & $\begin{array}{c}\text { Significant at } 1 \% \\
\text { Not Significant }\end{array}$ \\
Qatar - Oman & & 0.33197 & 0.7177 & Significant at $1 \%$ \\
Oman - Bahrain & 423 & 11.1262 & $0.00005^{*}$ & Significant at 5\% \\
Bahrain - Oman & & 3.25195 & $0.0397 *$ & \\
\hline
\end{tabular}

Note: $* * *, * * *$ indicate significance level at $1 \%, 5 \%$, and $10 \%$

Table 4 Granger Causality Direction $(\mathrm{lag}=2)$ post crisis

\begin{tabular}{|c|c|c|c|c|}
\hline Countries & Sample Size & F-Statistic & P-Value & Result \\
\hline Malaysia - Indonesia & 603 & 11.4774 & $0.00001 *$ & Significant at $1 \%$ \\
\hline Indonesia - Malaysia & & 7.98385 & $0.0004 *$ & Significant at $1 \%$ \\
\hline Turkey - Indonesia & 603 & 0.33736 & 0.7138 & Not Significant \\
\hline Indonesia - Turkey & & 3.69189 & $0.0255^{* *}$ & Significant at $5 \%$ \\
\hline Qatar-Indonesia & 603 & 4.91512 & $0.0076^{*}$ & Significant at $1 \%$ \\
\hline Indonesia - Qatar & & 0.5532 & 0.5754 & Not Significant \\
\hline Bahrain - Indonesia & 603 & 2.92015 & $0.0547 * * *$ & Significant at $10 \%$ \\
\hline Indonesia - Bahrain & & 4.79512 & $0.0086^{*}$ & Significant at $1 \%$ \\
\hline Oman - Indonesia & 603 & 4.16808 & $0.0159 * *$ & Significant at $5 \%$ \\
\hline Indonesia - Oman & & 1.62222 & 0.1983 & Not Significant \\
\hline Countries & Sample Size & F-Statistic & P-Value & Result \\
\hline Turkey - Malaysia & 603 & 0.26899 & 0.7642 & Not Significant \\
\hline Malaysia - Turkey & & 6.83731 & $0.0012 *$ & Significant at $1 \%$ \\
\hline Qatar-Malaysia & 603 & 1.11516 & 0.3285 & Not Significant \\
\hline Malaysia - Qatar & & 1.36819 & 0.2554 & Not Significant \\
\hline Bahrain - Malaysia & 603 & 0.10446 & 0.9008 & Not Significant \\
\hline Malaysia - Bahrain & & 4.4466 & $0.0121 * *$ & Not Significant \\
\hline Oman - Malaysia & 603 & 1.05278 & 0.3496 & Not Significant \\
\hline Malaysia-Oman & & 1.40067 & 0.2472 & Not Significant \\
\hline Qatar-Turkey & 603 & 1.58468 & 0.2059 & Not Significant \\
\hline Turkey - Qatar & & 1.17396 & 0.3099 & Not Significant \\
\hline Bahrain - Turkey & 603 & 0.13859 & 0.8706 & Not Significant \\
\hline Turkey - Bahrain & & 1.12372 & 0.3258 & Not Significant \\
\hline Oman - Turkey & 603 & 0.50479 & 0.6039 & Not Significant \\
\hline Turkey - Oman & & 0.64753 & 0.5237 & Not Significant \\
\hline Bahrain - Qatar & 603 & 2.28526 & 0.1026 & Not Significant \\
\hline
\end{tabular}




\begin{tabular}{|c|c|c|c|c|}
\hline Qatar-Bahrain & & 2.73175 & $0.0659 * * *$ & Significant at $10 \%$ \\
\hline Oman - Qatar & 603 & 4.17684 & $0.0158 * *$ & Significant at $5 \%$ \\
\hline Qatar-Oman & & 1.44336 & 0.237 & Not Significant \\
\hline Oman - Bahrain & 603 & 0.1222 & 0.885 & Not Significant \\
\hline Bahrain - Oman & & 5.24702 & $0.0055^{*}$ & Significant at $1 \%$ \\
\hline
\end{tabular}

Note: $* * *, * * *$ indicate significance level at $1 \%, 5 \%$, and $10 \%$

Table 5 Summary of Granger causality direction (lag $=2$ )

\begin{tabular}{|c|c|}
\hline \multicolumn{2}{|c|}{ During Crisis } \\
\hline Malaysia $=$ Indonesia & unidirectional \\
\hline Turkey = Malaysia & unidirectional \\
\hline Oman = Indonesia & unidirectional \\
\hline Malaysia = Qatar & bi-directional \\
\hline Indonesia = Qatar & bi-directional \\
\hline Indonesia $=$ Turkey & unidirectional \\
\hline Bahrain = Turkey & unidirectional \\
\hline Oman = Turkey & unidirectional \\
\hline Oman = Malaysia & unidirectional \\
\hline \multicolumn{2}{|c|}{ Post Crisis } \\
\hline Indonesia $=$ Malaysia & bi-directional \\
\hline Malaysia = Turkey & unidirectional \\
\hline Indonesia $=$ Bahrain & unidirectional \\
\hline Bahrain = Oman & unidirectional \\
\hline Qatar = Indonesia & unidirectional \\
\hline
\end{tabular}

The following table is the result for bounds tests of integration. The combination of the smallest value of AIC-SBC, lag-length criteria and observation technique on the insignificant correlogram of residuals of unrestricted VAR are applied to determine the optimal number of lags to be included in the models. Narayan et al. (2004) point out that the benefit of ARDL approach is we can estimate which series is the dependent variable from F-test when there is a cointegration. For 2008-2009 crisis, the F-test indicates that the null hypothesis of no cointegration among variable in Equation (1), (2), (5), and (6) cannot be rejected because the F-statistics is less than the lower bound critical values. While in the Equation (3) and (4) the result is inconclusive.

For the post-crisis period, the F-test illustrates the null hypothesis of no cointegration among variables in Equations (1), (2), (3), and (5) are not rejected, thus there is no evidence of integration. While for Equation (4) and (6) the F statistic for FQATR(.) and FOMAN(.) exceed the upper bound critical value at $1 \%$ and $5 \%$ level respectively. Therefore, there are long-run relationships between variables of Islamic stock prices in Qatar and Oman which are treated as the dependent variables.

After knowing the result of cointegration, we proceed to the lagged level of variables and estimate the long-run and short-run together with the relevant diagnostic tests for the short-run model when stock index in Qatar and Oman are the dependent variable in the post-crisis. Table 7 below illustrates the long-run coefficient and error correction model (ECM) of the selected ARDL models for post crisis period. The coefficients of the ECM for both Qatar and Oman are negative and highly significant at $1 \%$. These statistics confirm the present of a stable short-run relationship and indicate to a long-run relationship between variables. The coefficients of the ECM are -0.035901 and -0.023684 for Qatar and 
Oman, respectively suggesting that a deviation from the long-run equilibrium following a short-run disturbance is corrected by approximately $3.59 \%$ for Qatar and $2.36 \%$ for Oman after one month. In brief, the study finds that there is evidence of integration among the stock market in OIC countries.

Table 6 ARDL F-statistic test for co-integration

\begin{tabular}{clcc}
\hline Period & \multicolumn{1}{c}{ Equation } & F-statistic & \multicolumn{1}{c}{ Result } \\
\hline \multirow{3}{*}{ During Crisis } & F(INDO/MY,TURK,QATR,BAHR,OMAN) & 1.386371 & No integration \\
\cline { 2 - 4 } & F(MY/INDO,TURK,QATR,BAHRN,OMAN) & 0.545662 & No integration \\
\cline { 2 - 4 } & F(TURK/INDO,MY,QATR,BAHRN,OMAN) & 3.710969 & Inconclusive \\
\cline { 2 - 4 } & F(QATR/INDO,TURK,MY,BAHRN,OMAN) & 3.726335 & Inconclusive \\
\cline { 2 - 4 } F(BAHN/INDO,TURK,QATR,MY,OMAN) & 1.833704 & No integration \\
\hline \multirow{3}{*}{ Post Crisis } & F(INDO/MY,TURK,QATR,BAHR,OMAN) & 0.193259 & No integration \\
\cline { 2 - 4 } & F(MY/INDO,TURK,QATR,BAHRN,OMAN) & 1.255515 & No integration \\
\cline { 2 - 4 } & F(TURK/INDO,MY,QATR,BAHRN,OMAN) & 1.941611 & No integration \\
\cline { 2 - 4 } & F(BAHRN/INDO,TURK,MY,BAHRN,OMAN) & $5.751065 * * *$ & Integration \\
\cline { 2 - 4 } & F(OMAN/INDO,TURK,QATR,BAHRN,MY) & $3.825112^{* *}$ & Integration \\
\hline
\end{tabular}

Notes: The relevant critical value bounds are taken from Pesaran (2001): (i). Case (iii): unrestricted intercept and no trend (number of regressors = 5), they are $2.26-3.35$ at the $99 \% ; 2.62-3.79$ at the $95 \%$; and $3.41-4.68$ at the $90 \%$ significance levels respectively. $*$ denotes that F-statistics fall above the $90 \%$ upper bound, $* *$ denotes above the $95 \%$ upper bound and $* * *$ denotes above the $99 \%$ upper bound.

This result is in line with studies done by Ceylan and Dogan (2004), Ergun and Hassan (2009), Majid and Kassim (2010) where they claim that there is a long-run relationship in OIC countries. The degree of integration among Islamic stock markets among the OIC members depends on the level of economic development of the country that stock markets are in. The result documented that after 2007 crisis the Islamic stock markets of Malaysia and Indonesia are closely integrated with each other. The result recommends that if investors who are interested to diversify their portfolio can still gain benefits however limited benefits are available if investors only diversify their investments within the same economic grouping that are within the emerging Islamic stock market or within the developed Islamic stock markets.

There is similar result with study done by Kenani et al. (2013) whereas the integration only existed after the crisis for equation where Oman and Qatar are the dependent variable. Somehow sub-prime mortgage crisis in 2007 impacted significantly in the degree of cointegration for Islamic stock market integration. We can see that the integration after 10 January 2010 was increased among the six selected OIC members hence this result suggested that among these countries there are opportunity to make the Islamic stock market more efficient and competitive. Furthermore, this condition can benefit the market to lower its transaction cost in stock market and the possibility to gain higher return for the investors.

We relate to the empirical studies conducted by Darrat et al. (2000), Ceylan and Dogan (2004), Marashdeh (2005), Majid and Kassim (2010), Karim and Karim (2012), and Kenani et al. (2013), stock market linkage could give less benefit to the investor for portfolio diversification and the market become inefficient because it is predictable. However, in the case of OIC countries where they have difficulties to generate foreign trade volume due to small illiquid stock market, market integration could benefit them a lot in terms of cost saving. Claessens et al. (2003) mention that through stock market integration, efficiency could be achieved with many different sources namely economy of scale, sharing system for equity trading and harmonizing rules and requirements between stock exchanges with respect to trading and membership. We can conclude that different implication occurred between OIC countries and developed countries on stock market integration. 
Table 7 Estimated long run and short run coefficient using the ARDL approach

Post Crisis

\begin{tabular}{lll}
\hline & \multicolumn{1}{c}{ Long-Run Coefficient } \\
\hline Regressors & Qatar ARDL $(1,1,0,0,0,1)$ & Oman ARDL $(1,1,0,0,0,0)$ \\
Coefficient & Coefficient \\
\hline Indonesia & $0.13152^{* * * *(5.5589)}$ & $-0.0031533(-0.46527)$ \\
Turkey & $-0.015189^{* *}(-3.4177)$ & $0.0051762(1.2987)$ \\
Malaysia & $0.035108^{* *}(2.1043)$ & $-0.0039917(-0.26787)$ \\
Bahrain & $0.0010473(0.14969)$ & $0.010377 *(1.6723)$ \\
Oman & $0.18282^{* * *}(4.0136)$ & NA \\
Qatar & NA & $0.15806(0.15806)$ \\
Constant & $-0.043764(-0.30864)$ & $0.073275(0.58081)$
\end{tabular}

\begin{tabular}{lll}
\hline & \multicolumn{1}{c}{ Short-Run Coefficient } \\
\hline Regressors & Coefficient & Coefficient \\
\hline$\Delta$ Indonesia & $0.13152^{* * *}(5.5589)$ & $-0.0031533(-0.46527)$ \\
$\Delta$ Malaysia & $0.035108^{* *}(2.1043)$ & $-0.0039917(-0.26787)$ \\
$\Delta$ Turkey & $-0.015189^{* *}(-3.4177)$ & $0.0051762(1.2987)$ \\
$\Delta$ Bahrain & $0.0010473(0.14969)$ & $0.010377(1.6723)$ \\
$\Delta$ Oman & $0.18282^{* * *(4.0136)}$ & NA \\
$\Delta$ Qatar & NA & $0.15806 * * *(4.5193)$ \\
Constant & $-0.043764(-0.30864)$ & $0.073275(0.58081)$ \\
ECT (-1) & $-0.035901^{* * *}(-3.6762)$ & $-0.023684^{* * *}(-2.7743)$ \\
& & \\
\hline & & 0.98757 \\
$\mathrm{R}^{2}$ & 0.11433 & 0.98740 \\
Adjusted - R & 0.10091 & $0.72885[0.393]$ \\
$X_{\text {Auto }}^{2}$ & $16.7541[0.000]$ & $9660.0[0.000]$ \\
$X_{\text {Norm }}^{2}$ & $1840.6[0.000]$ & $0.22347[0.636]$ \\
$X_{\text {Reset }}^{2}$ & $0.40182[0.526]$ &
\end{tabular}

Note: Auto is the Breusch-Godfrey LM test for autocorrelation; Norm is the Jarque-Bera normality test; RESET is the Ramsey test for functional form. ***,**, and * indicate significance at the $1 \%, 5 \%$, and $10 \%$ levels, respectively. Figures in parentheses and square brackets represent t-statistics and p-value respectively.

\section{CONCLUSIONS}

This study examines the existence of Islamic stock market linkages among six selected OIC (Indonesia, Malaysia, Bahrain, Oman, Qatar, and Turkey) which caused by the impact of 2007 global crisis and to analyze whether the OIC Islamic stock markets are segmented or the international investors can get the benefits when allocating their funds across these markets. The tools to measure the relationship were applying ARDL (Autoregressive Distribution Lagged) and Engel-Granger (1987). The analysis was made for the sub period during crisis (3 September 2007 - 11 January 2010) and post crisis (18 January 2010 - 30 April 2013).

The finding of this study depicts that the markets is cointegrated after the global crisis and the interrelated market across OIC members could be gain limited benefit from portfolio diversification because the market was predictable. The result is consistent with prior study done by Kenani et al. (2013) where the market is cointegrated after the global financial crisis. However, in the case of OIC countries, there are many advantages can be gained through stock market integration such as market efficiency and competitiveness, cost saving for stock market transaction and possibility to get higher return. 
This study contributes toward the development of stock market within OIC community. Most of the OIC countries relies their country's income from export of natural resources, such oil or gas and agricultural. Moreover, the finding is viable not only to international portfolio investors but also to the policy makers who are responsible to develop good and efficient economic relationship among the OIC member countries.

With different maturity of Islamic stock market development, legal jurisdiction and income level in OIC members there should be a set of internationally acceptable standards which has a purpose to provide guidance for the development and implementation of this industry. Hence, the policy maker can form basic development of sound Islamic stock market in OIC countries.

\section{REFERENCES}

Beik, I.S., Wardhana, W. (2011). The relationship between Jakarta Islamic Index and other selected markets: Evidence from impulsive response function. Jurnal Ekonomi dan Bisnis Airlangga, 21(2), 100-109.

Ceylan, Nildă̆ Başak and Doğan, Burak. (2004). Comovements of stock markets among selected OIC countries. Journal of Economic Cooperation, 3, 47-62.

Claessens, S., Lee, R., \& Zechner, J. (2003). The future of stock exchanges in European Union Accession countries, Corporation of London, 1-35.

Darrat, A.F., Elkhal, K., \& Hakim, S.R. (2000). On the Integration of emerging stock markets in the Middle East. Journal of Economic Development, 25(2), 119-129.

Ergun, U. \& Hassan, S.M.N.A. (2009). Comovement and linkages of emerging stock markets : A case study from OIC member countries. Journal of Economic Cooperation and Development, 4(30), 105119.

Hassan, M.K. \& Yu, J.S. (2007). Stock exchange alliances in Organization of Islamic Cooperation (OIC). Working Paper. Network Financial Institute at Indiana State University, 2007-WP-18 July 2007.

Karim, B.A., Kassim, N.A.M., \& Arip, M.A. (2010). The subprime crisis and Islamic stock markets integration. International Journal of Islamic and Middle Eastern Finance and Management, 3(4), 363-371. doi:10.1108/17538391011093298.

Karim, B.A. \& Karim, Z.A. (2012). Integration of ASEAN-5 stock markets: A revisit. Asian Academy of Management Journal of Accounting and Finance, 8(2), 21-41.

Kassim, S. (2013). The global financial crisis and the integration of Islamic stock markets in developed and developing countries. Asian Academy of Management Journal of Accounting and Finance, 9(2), 75-94.

Kenani, J.M., Purnomo, J., \& Maoni, F. (2013). The Impact of the Global Financial Crisis on the Integration of the Chinese and Indonesian Stock Markets. International Journal of Economics and Finance, 5(9), 69-81. doi:10.5539/ijef.v5n9p69

Majid, M.S.A, Yusof, R.M., \& Razali, A.N. (2007). Dynamic financial linkages among selected OIC countries. Journal of Economic Cooperation among Muslim Countries, 28(2), 25-56.

Majid, M.S.A \& Kassim, S. (2010). Potential diversification benefits across Global Islamic Equity Markets. Journal of Economic Cooperation and Development, 4(31), 103-126.

Marashdeh, H. (2005). Stock market integration in the MENA region: An application of the ARDL bounds testing approach. Working Paper. Faculty of Business. University of Wollongong.

Trabelsi, M.A., (2011). The impact of the financial crisis on the global economy: Can the Islamic financial system help?. The Journal of Risk Finance, 12(1), 15-25.

Nor, M.I. (2012). Financial Market integration of Middle East and North African (MENA) countries. Asian Journal of Management Sciences and Education, 1(2), 63-72.

Hussin, M.Y.M., Yusof, YA., Muhammad, F., Razak, A.A., Hashim, E., \& Marwan, N.F. (2013). The integration of Islamic stock. Labuan e-Journal of Muamalat and Society, 7, 17-27.

Narayan, P.K. (2004). Reformulating critical values for the bounds f-statistics approach to cointegration: An application to the tourism demand model for Fiji (Discussion Paper No. 02/04). Australia: Department of Economics, Monash University. 
Neaime, S. (2005). Financial Market Integration and Macroeconomic Volatility in the MENA Region: An Empirical Investigation. Beirut.

Paskelin, O., Nguyen, C.V., \& Jones, K. (2013). Did financial market integration really happen in MENA region? An analysis. J. Econ. Coop. Dev, 34(1), 111-134.

Pesaran, M.H., Shin, Y. (1995). An autoregressive distributed lag modelling approach to cointegration analysis. Paper presented at the Symposium for Cetennial of Ragnar Frisch, Oslo, March 3-5, 1995.

Pesaran, M.H., Shin, Y., \& Smith, R.J. (2001). Bounds testing approaches to the analysis of level relationships. Journal of Applied Econometrics, 16, 289-326.

SESRIC. (2012). Islamic Finance in OIC Member Countries: OIC Outlook Series (p. 18). 